\title{
Toxic effects of herbicides on transplanted paddy
}

\author{
Chandra Bahadur Thapa \\ Department of Botany, Prithivi Narayan Campus, Tribhuvan University, Pokhara, Nepal \\ E-mail: cbthapa@yahoo.com
}

\begin{abstract}
The effectiveness of two herbicides viz., 2 4-D and butachlor for the control of weeds in transplanted paddy and improving the grain yield was studied. Slight toxic effect of herbicides on paddy plants was noticed at 21 days after transplanting of paddy seedlings. However, it didn't persist for long and had no overall harmful effect on grain yield. Both the herbicides produced satisfactory control of the weed population and dry matter. This resulted in a significant increase in grain yield over un-weeded control.
\end{abstract}

Key words: Herbicides, weeds, transplanted paddy, toxicity, grain yield

\section{Introduction}

Paddy (Oryza sativa L.) is the major cereal crop grown in Nepal. But its productivity is relatively very low. One of the reasons for its low productivity is severe weed infestation. Manual weeding (hand pulling) is still the major method of weed control generally being practiced by the farmers in Nepal, though it is laborious and time consuming. A crisis of farm labour is emerging in Nepal due to organization and industrialization as well as out going of labour force to other countries. Weed control through herbicides is an alternative choice under such a situation, though majority of the Nepalese farmers are poor and small land holders.

The herbicidal control of weeds solves the problem of labour and is relatively cheaper than the manual weeding, but there are certain negative impacts of herbicides on environment, human health and to some extent to grain quality. For example, butachlor slightly affected rice leaf chlorophyll and amino acid contents and 5 ppm butachlor and 2,4-D although exhibited some phytotoxic effects on crop plants, however, the symptoms disappeared 14 days after seeding. Sundaru (1983) reported that the 'japonica' cultivar was generally less susceptible to 2, 4-D injury than 'indica' and adapted more readily in low temperature (about $21^{\circ} \mathrm{C}$ ) and high altitude (about $1140 \mathrm{~m}$ ) conditions. De Datta and Baltazar (1996) reported that herbicide selectively plays a critical role in rice weed control. With most herbicides, rice may suffer no more than $30 \%$ initial injuries through chlorosis and stunting which disappears within 2 to 4 weeks.

\section{Materials and Methods}

The experiment was conducted during the Kharif (wet) season to study the effectiveness of herbicides in controlling weeds in transplanted paddy (var. Radha 7 and Khumal 5). Two herbicides along with one hand weeded check and one weedy check were tested in complete randomized block design with three replications. Thirty two days old paddy seedlings were transplanted (four seedling per till) at a space of $20 \times 15 \mathrm{~cm}^{2}$. Herbicides were applied four days after transplanting in the field. Phytotoxicity of herbicides on paddy crop injury was 
made by visual estimates at 3, 6 and 9 weeks after transplanting. Estimates were based on a percentage scale of 0 to 100 (Richard, 1998) and the percentage of phytotoxicity of herbicides was calculated by the formula.

Phytoxicity $(\%)=\frac{\text { Chlorophyll in control }- \text { chlorophyll in treatments }}{\text { Chlorophyll in control }} \times 100$

Data were analysed statically by analysis of variance 'ANOVA' (Rangaswamy, 1995; SAS, 1995). All means were separated using Duncan's Multiple Range Test (DMRT) at the $\mathrm{P}=0.05$ significance level.

\section{Results}

\section{Phytotoxicity of herbicides on paddy}

The toxic effects of herbicides on the paddy crop plant were observed by pigment analysis and by visual method (phytotoxic rating scale) and found that herbicides were toxic at early stage of plant growth and plants recovered gradually.

\section{Phytotoxicity of butachlor}

The pre-emergence application of butachlor $(1.5 \mathrm{~kg} / \mathrm{ha})$ showed toxic effect on paddy cultivars Radha 7 and Khumal 5. The toxic effects of butachlor on Radha 7 were 14, 5 and $2 \%$ in 21, 42 and 63 DAT, respectively. The values in Khumal 5 were 16, 6 and 3\%, respectively (Tab. 1). Results presented in table 2 also revealed that the pigment content of crop plants at the early stage of growth were less as compared with weedy. At 21 DAT, the lowest pigment content was recorded in butachlor treated plots. Butachlor treated plants suffered more pigment deficiency than 2, 4-D. Thus, after 63 DAT, the phytotoxic effect was negligible or nil.

Table 1. Toxicity rating of herbicide (mean \pm SD) on paddy var. Radha 7 and Khumal 5.

\begin{tabular}{|c|c|c|c|c|c|c|c|c|c|}
\hline \multirow{3}{*}{ Treatments } & \multirow{3}{*}{$\begin{array}{l}\text { Rate of } \\
\text { application } \\
\text { (kg/ha) }\end{array}$} & \multicolumn{4}{|c|}{ Radhe 7} & \multicolumn{4}{|c|}{ Khumal 5} \\
\hline & & \multicolumn{8}{|c|}{ Toxicity rating scale of 0-100 DAT } \\
\hline & & 21 & 42 & 63 & 84 & 21 & 42 & 63 & 84 \\
\hline Butachlor & 1.5 & $\begin{array}{c}14.0 \\
\pm 1.7 \mathrm{a}\end{array}$ & $\begin{array}{c}5.0 \\
\pm 0.9 \mathrm{a}\end{array}$ & $\begin{array}{c}2.0 \\
\pm 0.1 \mathrm{a}\end{array}$ & $0.0 \mathrm{a}$ & $\begin{array}{c}16.0 \\
\pm 1.9 \mathrm{a}\end{array}$ & $\begin{array}{c}6.0 \\
\pm 1.0 \mathrm{a}\end{array}$ & $\begin{array}{c}3.0 \\
\pm 0.3 \mathrm{a}\end{array}$ & $0.0 \mathrm{a}$ \\
\hline $2,4 \mathrm{D}$ & 1.0 & $\begin{array}{c}17.0 \\
\pm 1.9 \mathrm{~b}\end{array}$ & $\begin{array}{c}6.0 \\
\pm 1.0 \mathrm{~b}\end{array}$ & $\begin{array}{c}3.0 \\
\pm 0.2 \mathrm{~b}\end{array}$ & $0.0 \mathrm{a}$ & $\begin{array}{c}19.0 \\
\pm 2.1 \mathrm{~b}\end{array}$ & $\begin{array}{c}8.0 \\
\pm 1.7 \mathrm{~b}\end{array}$ & $\begin{array}{r}3.0 \\
\pm 0.4 \mathrm{a}\end{array}$ & $0.0 \mathrm{a}$ \\
\hline
\end{tabular}

Mean \pm SD in each column followed by the same letter do not differ significantly at $\mathrm{P}=0.05$ by Duncan's Multiple Range Test (DMRT) followed after ANOVA.

\section{Phytotoxicity of 2, 4-D}

The pre-emergence application of 2, 4-D (1.0 kg/ha) showed toxic effect on paddy (Radha 7 and Khumal 5). The toxic effects of 2, 4-D on Radha 7 were 17, 6 and 3\% in 21, 42 and 63 DAT, respectively. The values in Khumal 5 were 19,8 and $3 \%$, respectively (Tab. 1). Results of pigment analysis indicated that 2, 4-D was toxic at early stages showing leaf chlorosis.

The results of butachlor and 2, 4-D treatments showed that Khumal 5 was slightly more sensitive to herbicide than Radha 7 and herbicide 2, 4-D was slightly more toxic to the paddy plants. At the initial stage of crop growth both herbicides showed phytotoxicity on 
paddy plants but toxic effect did not persist for long, it was high at early stage and gradually decreased. It had ultimately no deleterious effect on the mature plant at 84 DAT (Tabs. 1, 2).

Table 2. Toxicity effect of herbicide (mean \pm SD) on paddy var. Radha 7 and Khumal 5.

\begin{tabular}{|c|c|c|c|c|c|c|c|c|c|}
\hline \multirow{3}{*}{ Pigments } & \multirow{3}{*}{ Treatments } & \multicolumn{4}{|c|}{ Radhe 7} & \multicolumn{4}{|c|}{ Khumal 5} \\
\hline & & \multicolumn{8}{|c|}{ Days after transplanting (DAT) } \\
\hline & & 21 & 42 & 63 & 84 & 21 & 42 & 63 & 84 \\
\hline \multirow{15}{*}{ 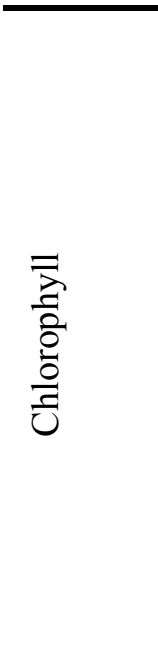 } & Weedy $\left(\mathrm{T}_{0}\right)$ & 1.34 & 1.40 & 1.38 & 1.34 & 1.25 & 1.28 & 1.27 & 1.21 \\
\hline & & $\pm 0.06 \mathrm{~b}$ & $\pm 0.07 \mathrm{a}$ & $\pm 0.06 \mathrm{a}$ & $\pm 0.06 \mathrm{a}$ & $\pm 0.06 \mathrm{~b}$ & $\pm 0.06 \mathrm{a}$ & $\pm 0.06 \mathrm{a}$ & $\pm 0.06 \mathrm{~d}$ \\
\hline & & $(0.0)$ & $(0.0)$ & $(0.0)$ & $(0.0)$ & $(0.0)$ & $(0.0)$ & $(0.0)$ & $(0.0)$ \\
\hline & Weed free & 2.53 & 2.90 & 3.67 & 2.70 & 2.12 & 2.52 & 2.91 & 2.29 \\
\hline & (TT) & $\pm 0.07 \mathrm{~d}$ & $\pm 0.13 \mathrm{e}$ & $\pm 0.19 \mathrm{e}$ & $\pm 0.13 \mathrm{~d}$ & $\pm 0.11 \mathrm{c}$ & $\pm 0.12 \mathrm{f}$ & $\pm 0.14 \mathrm{e}$ & $\pm 0.11 \mathrm{e}$ \\
\hline & & $(88.8)$ & (107.1) & (165.9) & (101.5) & $(69.6)$ & (96.9) & (129.1) & (89.3) \\
\hline & HW on 21 & 1.41 & 2.36 & 2.93 & 1.91 & 1.29 & 1.93 & 2.16 & 1.68 \\
\hline & $\operatorname{DAD}\left(\mathrm{T}_{1}\right)$ & $\pm 0.07 \mathrm{c}$ & $\pm 0.11 \mathrm{~d}$ & $\pm 0.14 \mathrm{~b}$ & $\pm 0.09 \mathrm{~b}$ & $\pm 0.06 \mathrm{~b}$ & $\pm 0.09 \mathrm{e}$ & $\pm 0.10 \mathrm{~b}$ & $\pm 0.08 \mathrm{~b}$ \\
\hline & & $(5.2)$ & $(68.6)$ & (112.3) & $(42.5)$ & $(3.2)$ & $(50.8)$ & $(70.1)$ & $(38.8)$ \\
\hline & Butachlor & 1.23 & 2.16 & 3.15 & 2.00 & 1.15 & 1.52 & 2.17 & 1.66 \\
\hline & $\left(\mathrm{T}_{2}\right)$ & $\pm 0.006 \mathrm{a}$ & $\pm 0.10 \mathrm{~b}$ & $\pm 0.15 \mathrm{c}$ & $\pm 010 \mathrm{c}$ & $\pm 0.06 \mathrm{a}$ & $\pm 0.07 \mathrm{~b}$ & $\pm 0.10 \mathrm{~b}$ & $\pm 0.08 \mathrm{~b}$ \\
\hline & & $(-8.2)$ & $(54.3)$ & (128.3) & (49.3) & $(-8.0)$ & (18.8) & $(70.9)$ & $(37.7)$ \\
\hline & $2,4-\mathrm{D}\left(\mathrm{T}_{3}\right)$ & 1.26 & 2.18 & 3.15 & 2.02 & 1.16 & 1.68 & 2.19 & 1.68 \\
\hline & & $\pm 0.06 \mathrm{ab}$ & $\pm 0.10 \mathrm{~b}$ & $\pm 0.15 \mathrm{c}$ & $\pm 0.10 \mathrm{c}$ & $\pm 0.06 \mathrm{a}$ & $\pm 0.08 \mathrm{c}$ & $\pm 0.10 \mathrm{~b}$ & $\pm 0.08 \mathrm{~b}$ \\
\hline & & $(-6.0)$ & $(55.7)$ & (128.3) & $(50.7)$ & $(-7.2)$ & $(31.3)$ & $(72.4)$ & $(38.8)$ \\
\hline
\end{tabular}

Mean \pm SD in each column followed by the same letter do not differ significantly at $\mathrm{P}=0.05$ by Duncan's Multiple Range Test (DMRT) followed after ANOVA; HW= Hand weeding, figure in parenthesis indicate $\%$.

\section{Discussion}

In spite of weeding in agricultural fields since time immemorial, the problems of weeds persist affecting the crop yields. The farmers in developed countries and many developing countries have undertaken chemical means of weed control. In Nepal, most of the farmers still practice hand weeding. The major reasons of traditional practice of weed removal in paddy fields are the poor economy, small size of the farms amd lack of basic understanding of the herbicide application techniques to control weeds. As a result of traditional agriculture, productivity is less.

Both the herbicides butachlor and 2, 4-D showed phyto-toxicity to crop at early stage of growth period but the crops recovered later on. The results of visual observation as well as chlorophyll analysis data of the present study on phyto-toxicity are in agreement with those obtained by De Datta et al. (1968, 1971), Maiti and Mishra (1985). 2, 4-D is slightly more toxic than butachlor for paddy and khumal 5 was slightly more sensitive than Radha 7 for herbicides. De Datta (1981) also reported that butachlor and 2, 4-D exhibited some phytotoxic effects, however, the symptoms disappeared later on. Sen (1981) opined that 2, 4-D is more toxic to rice when applied to the water in which the crop is growing. Very high or low temperature also influence the toxicity of 2, 4-D. Chemical weed control gave better results in Khumal 5 and it was similar to one weeding treatment.

Chlorophyll is the main instrument responsible for photosynthesis. Decrease in chlorophyll content directly effects photosynthesis and thus growth parameters. Chlorophyll content was 
significantly reduced in the herbicide treated paddy plots in the early stage of growth but the crop recovered later on. There are several reports highlighting effects of herbicide on chlorophyll in various crops (Moreland, 1969; Purohit et al., 1977; Rao \& Dubey, 1983; Nandihalli \& Bhowmik, 1992; Singh et al., 1996; Kushwaha \& Bhowmik, 1999) in agreement with the present findings.

In the present investigation Butachlor and 2, 4-D alone has been found not sufficient to control weeds. Generally, herbicides have been found less effective for narrow leaved monocot weeds and late emerging weeds. Hand weeding has been found better control of weeds specially narrow leaved monocot weeds and regeneration of the weeds after 42 DAT were not effective in crop yield reduction. Similar results have also been reported by Zhang $(1996,2001)$.

\section{Acknowledgements}

The author is thankful to Prof. Dr. P.K. Jha, Head, Central Department of Botany, Tribhuvan University for guidance and encouragement. I am also very much thankful to Prof. Dr. Sasinath Jha, Head, Department of Botany, Post Graduate Campus, Biratnagar for going through the manuscript and providing valuable suggestions.

\section{References}

De Datta, S.K. 1981. Weed control in rice in south and southeast Asia. In: Weeds and weed control in Asia. Food and Fertilizer Technology Centre (FFTC), Taiwan, Republic of China. 20: 1-24.

De Datta, S.K. \& A.M. Baltazar. 1996. Weed control technology as a component of rice production systems. In: Weed management in rice (Eds. B.A. Auld \& K.U. Kim). FAO Plant Production and Protection Paper. Food and Agriculture Organization of the United Nations (FAO), Rome, Italy. 139: 25-52.

De Datta, S.K., J.K. Park \& J.E. Howes. 1968. Granular herbicides for controlling grasses and other weeds in transplanted rice. Int. Rice Comm. Newsl. 17(4): 21-29.

De Datta, S.K., R.Q. Lacsina \& D.E. Seaman. 1971. Phenoxyacid herbicides for barnyard grass control in transplanted rice. Weed Sci. 19: 203-206.

Kushwaha, S. \& P.C. Bhowmik. 1999. Inhibition of pigment biosynthesis in cucumber cotyledons by isoxaflotole. Photosynthetica 37(4): 553-558.

Maiti, M.M. \& G. Misra. 1985. Control of weeds in transplanted rice with herbicides. Oryza 22: 150-155.

Moreland, D.E. 1969. Inhibitors of chloroplast electron transport; structural activity reactions. In: Progress in photosynthesis research III (Ed. M. Helmut). pp 1693-1711.

Nandihalli, U.B. \& P.C. Bhowmik. 1992. Inhibition of chlorophyll and carotenoid biosynthesis by the herbicide ICIA-0051. Photosynthetica 26(3): 355-362.

Purohit, M., P. Mall \& P.S. Dubey. 1977. Herbicidal pollution-chlorohyll content as an index of residual toxicity. Curr. Sci. 40: 157-158.

Rangaswamy, R. 1995. A textbook of agricultural static. New Age International Publisher Ltd., New Delhi, India.

Rao, A.N. \& P.S. Dubey. 1983. Growth, pigment concentration and yield of Sorghum cv vidisha as influenced by triazine herbicides. Indian J. Weed Sci. 15(1): 23-28. 
Richard, E.P. 1998. Control of perennated Bermuda grass (Cynodon dactylon) and Johnson grass (Sorghum lelepense) in sugarcane (Saccharum spp. hybrid). Weed Technol. 12: 128-133.

SAS. 1995. SAS User's guide: Stastistical analysis systems. Institutes. Cary. NC. 27513.

Sen. D.N. 1981. Ecological approaches to indian weeds. Geobios International, Jodhpur, India.

Sing, T., B.D. Sharma, R. Mangat \& R.S. Panwar. 1996. Effect of chemical weed control on nutrient uptake by tori (Brassica compestris var. tori) and associated weeds. Annals of Biology, Ludhiana 12(2): 274-277.

Sundaru, M. 1983. The growth and physiological response of several Indonesian rice varieties and paddy weeds to 2, 4-D with reference to ethylene. Memoirs of the Tokyo University of Agriculture, Tokyo, Japan. 25: 35-88.

Zhang, Z.P. 1996. Weed management in transplanted rice. In: Weed management in rice (Eds. B.A. Auld \& K.U. Kim). FAO Plant Production and Protection Paper. Food and Agriculture Organization of the United Nations (FAO), Rome, Italy. 139: 77-86.

Zhang, Z.P. 2001. Agricultural weeding in conjunction with herbicide application in Rice. In: Proc. $18^{\text {th }}$ Asian Pacific Weed Sci. Soc. Conf. May 28 - June 2, 2000. Standard Press of China, Beijing, China. pp. 211-214. 